\title{
Resource Utilization Pattern with Special Reference to Fodder and Fuel in Village Shahdarah Sharief, District Rajouri (J\&K)
}

\author{
SIMAB QURESHI, SHAHIMA AKHTER and PIYUSH MALAVIYA*
}

\author{
Department of Environmental Sciences, University of Jammu, Jammu-180006 (J\&K) India. \\ ${ }^{*}$ Corresponding author E-mail: piyushmalaviya @ rediffmail.com
}

http://dx.doi.org/10.12944/CWE.10.1.27

(Received: March 16, 2015; Accepted: April 15, 2015)

\begin{abstract}
The present study was conducted to understand fodder and fuel utilization pattern in village Shahdarah Sharief, Rajouri, India. The common fodder types used were green fodder, top feeds, crop residues and tree leaves. The green fodder consumption was found to be highest $(16.83 \mathrm{~kg} /$ day/family) while top feed was least utilized $(1.10 \mathrm{~kg} /$ day/family). The major fuel types fulfilling the energy demand of local people in study area were wood, LPG and dung cake. LPG constituted the major share of consumption $\left(10.7 \times 10^{5} \mathrm{kcal} /\right.$ month) while dung cake consumption was least $\left(3.1 \times 10^{5}\right.$ $\mathrm{kcal} / \mathrm{month})$. The total fuel and fodder consumption in study area was $17.2 \times 10^{5} \mathrm{kcal} / \mathrm{month}$ and 36.65 $\mathrm{kg} /$ day/family, respectively. Livestock population of study area was comprised of cow, bullock, buffalo, he-buffalo, goat and sheep with highest share of buffaloes $(43.38 \%)$ and lowest of he-buffaloes (4.42\%).
\end{abstract}

Key words: Fodder, Fuel, Livestock, Resource.

\section{INTRODUCTION}

Forests are deemed to be the green lung of the nation and act as important natural resource for rural livelihood in India, providing variety of products and services. The rural population in most of the developing countries depends mostly on forests mainly for fuel wood and fodder. The energy use pattern in rural India is changing with introduction of clean energy but traditional fuels including fuel wood, crop residue and cow dung still constitute the main source of household cooking energy due to inadequate and unreliable supply of clean energy ${ }^{1}$. In rural India, over $77 \%$ households depend on fuel wood and wood chips for cooking, whereas $9 \%$ use LPG and the same number $(9 \%)$ is using dung cakes ${ }^{2}$. Resource demands of fuel and fodder are also high in Jammu and Kashmir due to its temperate, dry and cold arid conditions. Large quantities of energy is required as fuel for cooking of food as well as for keeping houses warm during severe winters. To meet the demands of fuel wood, the households usually depend on forests or other community lands whereas a little is obtained from agriculture fields and markets. In high altitude villages of Kashmir and Ladakh regions, it is reported that fuel wood and kerosene are the two main sources of energy ${ }^{3}$.

Significant work on resource utilization pattern in Himalayan states of India has been conducted by various workers ${ }^{4,5,6,7}$ and some studies have also been reported from Northwestern Himalayan state of Jammu and Kashmir ${ }^{8,9,10}$. Due to exploitation of huge quantities of fuel and fodder resources, there is a detrimental impact on the forests which results in deforestation, erratic rainfall, soil erosion, loss of habitat, loss of biodiversity etc. Due to increase in population and changing socioeconomic conditions of the people, fuel, fodder, timber and other forest resources are becoming scarce. Thus, it is necessary to know the resource availability and resource utilization patterns which affect the fuel wood and fodder availability in a 
particular area. Keeping this in view, the present study was conducted in the village Shahdarah Sharief of district Rajouri to study socio-economic status, and fodder and fuel utilization pattern in the study area.

\section{MATERIALS AND METHODS}

\section{Study area}

The study area lies in the village Shahdarah Sharief of district Rajouri and located between $32^{\circ}$ $58 \phi$ and $33^{\circ}-35 \phi$ North Latitude and 70 and $74^{\circ}-4 \phi$ East Longitude at an altitude of 1668 meters above sea level. The village is $29 \mathrm{~km}$ away from Rajouri Town and $177 \mathrm{~km}$ away from Jammu. The climate is sub-tropical with the temperature ranges from $23-34^{\circ} \mathrm{C}$ in summer season while it reaches to 15 $7^{\circ} \mathrm{C}$ during winters. The main occupation of people is agriculture and rearing of cattle. The study area has hilly terrain and most of the cultivable lands are located in the slopes where irrigation is not possible and depends completely on rainwater for irrigation. The average land holding is moderate and majority of the families come under middle class income group. The inhabitants in the study area meet their fodder and fuel wood requirement mainly by cutting and lopping of trees from the agricultural fields, forests and homestead area.

\section{Data collection and analysis}

A detailed questionnaire was prepared which involved various aspects such as demographic status of the area, asset holding, types of occupation, land use pattern, detail of bovine population, infrastructural facilities, resources endowment, quantity and types of fuel and fodder consumed. The survey was conducted on door to door basis covering 30 percent of the households on random basis from center of the village to the periphery to obtain the real pattern of information.

The survey of demographic status of the study area involved the use of adult units i.e., one $\operatorname{man}=1$ adult unit, one women $=0.8$ adult unit and one child=0.5 adult unit so as to find out the average size of family ${ }^{11}$. For calculating the landholding the units used were, one kanal $=1 / 8$ Acre, and one hectare $=2.471$ Acres. All kinds of livestock in the sample household were converted into cow units using equality coefficients i.e., 1 cow unit for one cow, 1.5 cow units for one buffalo, 0.15 cow unit for one goat/sheep and 1.5 cow unit for one bullock ${ }^{12}$. Units used for quantity of animal droppings were $15 \mathrm{~kg} / \mathrm{day}, 10 \mathrm{~kg} / \mathrm{day}$ and $02 \mathrm{~kg} /$ day for bullock/ buffalo/ he-buffalo, cow and sheep/ goat, respectively ${ }^{13}$. Energy units used for different fuel types were, one $\mathrm{kg}$ firewood $=4000 \mathrm{k}$.cal, one $\mathrm{kg}$ dung cake $=2400 \mathrm{k} . c a l$, one $\mathrm{kg}$ crop residue $=3200$ k.cal, one $\mathrm{kg}$ of $L P G=10800 \mathrm{k} . \mathrm{cal}$ and one liter kerosene $=7900 \mathrm{k} . c a l^{14}$. Similarly, for collection of the relevant information regarding fuel wood and fodder the season of the year has also been taken in to consideration e.g., during winter fuel wood requirements is more and during rainy/spring season, large quantity of various types of fodder is available for the cattle.

\section{RESULTS AND DISCUSSION}

An exploratory study was carried out at household level to find out the annual income, land holdings, cow units per household, dung produced per household, literacy status, infra-structural facilities, fuel and fodder consumption pattern with its environmental impacts interrelating socio-economic and demographic factors in the study area.

\section{Socio-economic and literacy status}

Population of the study area was divided into four categories viz., very low, low, medium and high on the basis of their monthly income. The representation of high income class group was found to be higher ( $90 \%)$, followed by very low, low and medium income classes group i.e. 3.33\% each (Table 1). The highest representation of high income class was due to the reason that they had high land holding, for agriculture use and comparatively high rate of employment in government jobs. However, Akhter and Malaviya (2014) ${ }^{10}$ in her study in village Chak Chua of district Jammu found a high gap between medium income classes and other income classes due to the reasons that medium income class had large land holding and at least one of the family members was employed. The average annual income per family in the study area was found to be Rs.1,42,933.33. It was found that families belonged to small land holding category represented the highest land holding (83\%), followed by medium land holding category (16\%) (Table 2). No family in the study area was found to be in 
large and marginal land holding category. It was observed that the households belonged to small land holding category were having highest share in total land holding $(74.44 \%)$, followed by medium land holding category (25.55\%). Whole of the land belonged to non-irrigated category because of lack of irrigation facilities in the study area ${ }^{15}$. Literacy status of males and females in the study area was $64 \%$ and $36 \%$, respectively. It was low as compared to the overall literacy status of Jammu and Kashmir which is $78.26 \%$ for males and $58.01 \%$ for females.

Table 1: Representation of various income classes in the study area

\begin{tabular}{lcc}
\hline S. No. & Income class $^{*}$ & Families (\%) \\
\hline 1 & Very low & 3.33 \\
2 & Low & 3.33 \\
3 & Medium & 3.33 \\
4 & High & 90.0
\end{tabular}

*Very low < Rs 2500 per month, Low Rs 2500-3500 per month, Medium Rs 3500-5000 per month, High Rs 5000 per month;
Comparatively low literacy rate among females was probably due to the fact that people were not aware about the importance of women literacy ${ }^{10,16}$.

\section{Livestock resource and dung production}

Livestock population of study area was comprised of cow, bullock, buffalo, he-buffalo, goat and sheep. According to table 3, the highest share among total bovine population was shown by buffaloes (43.38\%) and lowest by he-buffaloes $(4.42 \%)$. The reason behind the largest population of buffaloes was the dependency of villagers on buffalos for milk and milk products which help them to generate income. The survey revealed that highest amount of dung was produced by buffalo $(29.5 \mathrm{~kg} /$ day/family) and lowest by goat ( $1.4 \mathrm{~kg} /$ day/family). The contribution of sheep in dung production was $6.6 \mathrm{~kg} /$ day/family, followed by bullock ( $5 \mathrm{~kg} /$ day/ family). Cow and he-buffalo both produced $3 \mathrm{~kg}$ dung/ day/family. However, Akhter and Malaviya (2014) $)^{10}$ in village Chak Chua, Jammu, reported very low amount of dung produced by goat/sheep (1.2 kg/ day/family) and highest amount of dung produced by cow (16 kg/day/family) due to more share of bovine population. Kumar (2002) $)^{16}$ also reported highest

Table 2: Land use pattern in the study area

\begin{tabular}{|c|c|c|c|c|}
\hline \multirow{2}{*}{$\begin{array}{l}\text { Land holding } \\
\text { category(LHC)* }\end{array}$} & \multirow{2}{*}{$\begin{array}{l}\text { Representation } \\
\text { of families (\%) }\end{array}$} & \multirow{2}{*}{$\begin{array}{c}\text { Share of LHCs in } \\
\text { total land holding (\%) }\end{array}$} & \multicolumn{2}{|c|}{ Pattern of land holding (\%) } \\
\hline & & & Irrigated & Non-irrigated \\
\hline Large & - & - & - & 100 \\
\hline Medium & 16 & 25.550 & - & 100 \\
\hline Small & 83 & 74.442 & - & 100 \\
\hline Marginal & - & - & - & 100 \\
\hline
\end{tabular}

*Marginal<0.1 hectare, Small 0.1-1 hectare, Medium 1-2 hectare, Large >2

Table 3: Details of the bovine population in the study area

\begin{tabular}{lcc}
\hline $\begin{array}{l}\text { Animal } \\
\text { type }\end{array}$ & $\begin{array}{c}\text { Share of bovine } \\
\text { population } \\
(\%)\end{array}$ & $\begin{array}{c}\text { Amount of dung } \\
\text { produced } \\
\text { (kg/day/family) }\end{array}$ \\
\hline Cow & 06.61 & 3 \\
Bullock & 15.44 & 5 \\
Buffalo & 43.38 & 29.5 \\
He-buffalo & 04.41 & 3 \\
Goat & 15.44 & 1.4 \\
Sheep & 14.70 & 6.66 \\
\hline
\end{tabular}

amount of dung produced by cow i.e. $30 \mathrm{~kg} / \mathrm{day} /$ family in Dandesar Village of district Rajouri.

\section{Fodder consumption pattern}

Common types of fodder used in the study area were found to be green fodder, top feed, crop residue and tree leaves. The average quantity of different types of fodder required per day per family, percentage of their total requirement, source of their collection and average distance covered for collection $(\mathrm{km})$ is given in Table 4. The green fodder consumption was found to be highest $(16.83 \mathrm{~kg} /$ day/family), followed by crop residue $(13.16 \mathrm{~kg} / \mathrm{day} /$ 
family), tree leaves (5.56 kg/day/family) and top feed (1.1 kg/day/family). The percentage consumption of green fodder was higher $(45.90 \%)$ and least percentage consumption was recorded for top feed $(3 \%)$. These results were similar to the study conducted by Sati and Sang $(2011)^{17}$ in Uttarakhand Himalaya and found that the fodder and fuel wood with drawl and consumption varied with regions and also by slopes. It has been observed that the consumption of green fodder varies in different seasons because of the availability of rain water in rainy season, green fodder dominate in the study area.

\section{Fuel consumption pattern}

The study of fuel consumption pattern was conducted among different land holding categories (LHCs) showed that the major fuel types consumed in the study area were wood, LPG and dung cake. The percent utilization of each fuel type among different LHCs is given in Table 5. Fuel wood consumption was highest in case of medium LHC. It was observed that fuel wood extraction was higher in winter as compared to summer because of heating requirements. Similar results were found by Rawat and Sharma (2010) ${ }^{18}$ who worked in district Rudra-prayag of central Indian Himalayas. It was

Table 4: Fodder consumption pattern in the study area

\begin{tabular}{lcccc}
\hline Fodder type & $\begin{array}{c}\text { Quantity required } \\
\text { (day/family/kg) }\end{array}$ & $\begin{array}{c}\text { \% of total } \\
\text { requirement }\end{array}$ & $\begin{array}{c}\text { Source of } \\
\text { collection }\end{array}$ & $\begin{array}{c}\text { Average distance } \\
\text { covered for } \\
\text { collection (Km) }\end{array}$ \\
\hline Green fodder & 16.83 & 45.90 & Agriculture fields & 0.5 \\
Top feed & 1.10 & 3 & Market & 10 \\
Crop residue & 13.16 & 35.90 & Agricultural fields & 0.5 \\
Tree leaves & 5.56 & 15.18 & Forest land & 2.0 \\
\hline
\end{tabular}

Table 5: Fuel use pattern in the study area

\begin{tabular}{|c|c|c|c|c|}
\hline \multirow{2}{*}{$\begin{array}{l}\text { Land } \\
\text { holding } \\
\text { Category }\end{array}$} & \multicolumn{3}{|c|}{ Fuel in use (kcal/month) } & \multirow{2}{*}{$\begin{array}{c}\text { Dung cake } \\
\text { kcal/ } \\
\text { month }\end{array}$} \\
\hline & Wood & LPG & Kerosene & \\
\hline Marginal & - & - & - & - \\
\hline Small & $1.1 \times 10^{5}(33.33 \%)$ & $7.5 \times 10^{5}(70.09 \%)$ & - & $2.1 \times 10^{5}(67.74 \%)$ \\
\hline Medium & $2.2 \times 10^{5}(66.66 \%)$ & $3.2 \times 10^{5}(29.09 \%)$ & - & $1.0 \times 10^{5}(32.25 \%)$ \\
\hline Large & - & - & - & \\
\hline Total & $3.3 \times 10^{5}$ & $10.7 \times 10^{5}$ & - & $3.1 \times 10^{5}$ \\
\hline
\end{tabular}

Table 6: Fuel requirement in the study area

\begin{tabular}{lccc}
\hline $\begin{array}{l}\text { S. } \\
\text { No. }\end{array}$ & $\begin{array}{c}\text { Type of } \\
\text { fuel }\end{array}$ & $\begin{array}{c}\text { Total fuel used } \\
\text { (kcal/month) }\end{array}$ & $\begin{array}{c}\text { Percent } \\
\text { share }\end{array}$ \\
\hline 1 & LPG & $10.7 \times 10^{5}$ & 62.57 \\
2 & Kerosene & - & - \\
3 & Wood & $3.3 \times 10^{5}$ & 19.30 \\
4 & Dung cake & $3.1 \times 10^{5}$ & 18.13 \\
& Total & $17.1 \times 10^{5}$ & 100 \\
\hline
\end{tabular}

found that LPG consumption was higher in small LHC (70.09\%), followed by medium LHC (29.09\%). The highest consumption of LPG by small LHC can be attributed to higher representation of the small LHC in the study area. The consumption of dung cake as a fuel was found to be highest in small LHC $(67.741 \%)$ because of large bovine population while dung cake use was less in medium LHC (32.25\%). The fuel requirement in the study area is represented in Table 6. The highest percentage consumption in study area was that of LPG $(62.57 \%)$, followed by 
fuel wood (19.76\%) and dung cake (18.13\%). It was found that consumption of kerosene oil was nil. Total fuel consumption in study area (Kcal/month) was calculated to be $17.2 \times 10^{5} \mathrm{kcal} / \mathrm{month}$, which is very low as reported $\left(111.49 \times 10^{6} \mathrm{kcal} / \mathrm{month}\right)$ by Kumar $(2002)^{16}$ in Dandasar village of district Rajouri.

\section{Environmental issues in the study area}

The people of study area were greatly dependent on the local forests for the extraction of fuel wood and timber. The timber and fuel wood were used for various household purposes. Buxus wallichiana (Chikarri wood) was used for making wooden articles. Due to its over extraction only few trees were observed in the study area. Timber was used for construction of wooden planks for houses whereas fuel wood was used for cooking and heating purpose which further generates smoke and cause indoor air pollution. Many other uncontrolled activities like deforestation, faulty agricultural practices, overgrazing, unplanned developmental activities were found to be responsible for enhancing soil erosion and landslide in the study area. Lack of proper sanitation and unhygienic conditions were prevailing in several households especially those belonged to lower income groups due to deficient infrastructure facilities and awareness. Washing and bathing activities of villagers were the main cause of polluted water bodies. Cleaning of cattle in water bodies and mixing of animal as well as human excreta also led to water pollution in the study area.

\section{CONCLUSION}

The study area has experienced many challenges in its fuel and energy consumption patterns both in quantitative as well as qualitative terms, mainly due to increase in population growth, economic activity and development. Thus, appropriate measures e.g. regeneration and ecodevelopment of degraded forests are needed for the protection and conservation of natural resources in the study area. Villagers must be encouraged for the use of renewable energy resources like solar energy. Community biogas plants should be initiated to provide clean, green and convenient fuel for cooking along with development of water harvesting structures so as to create facilities for irrigation purpose. Proper awareness to villagers should be provided over sanitation issues to create a healthy and disease free environment.

\section{REFERENCES}

1. Das, D., and Srinivasan, R. Income levels and transition of cooking fuel among rural poor in India. Energy Science and Technology, 4: 85-91(2012).

2. National Sample Survey Organization. Energy used by Indian household. National Sample Survey Organization. Department of Statistics. New Delhi (2007-8).

3. Hussain, H. Fuel consumption pattern in high altitude of Kashmir and Ladakh. Energy Environment Monitor, 3: 52-56 (1987).

4. Chettri N., and Sharma, E.A. Scientific assessment of traditional knowledge on firewood and fodder values in Sikkim, India. Forest Ecology and Management, 257: 20732078 (2009).

5. Raizada, A., Dogra, P., and Dhyani, B.L. Assessment of a multi-objective decision support system generated land use plan on forest fodder dependency in a Himalayan watershed. Environmental Modelling and
Software, 23: 1171-1181(2008).

6. Singh, N., and Sundriyal, R.C. Fuelwood, fodder consumption and deficit pattern in Central Himalayan village. Nature and Science, 7: 85-88 (2009).

7. Dhyani, S., Maikhuri, R.K., and Dhyani, D. Energy budget of fodder harvesting pattern along the altitudinal gradient in Garhwal Himalaya, India. Biomass and Bioenergy, 35:1823-1 832 (2011).

8. Tomar S.K., and Lall, D. Feeding practices and livestock productivity in Kashmir valley. International journal of Animal Science, 7: 61-65 (1992).

9. Gupta, T., Gupta, R.K., and Raina, K.K. Socio-economic factors associated with fuel consumption pattern in rural habitation of Jammu region, Jammu \& Kashmir. Indian Journal of Forestry, 32: 387-390 (2009).

10. Akhter, S., and Malaviya, P. Resource utilization pattern with special reference to 
fuel and fodder in village Chak Chua, district Jammu. International Research Journal of Earth Sciences, 2: 21-27 (2014).

11. Sharma, S. Fuel wood and fodder energy utilization pattern in Rui Watershed of Jammu region. M.Sc. Dissertation, G.B. of Agriculture and Technology, Pant Nagar (1993).

12. Jackson, J.C. Exploring livestock incomes in Zimbabwe's Communal Lands. People, land and livestock, Proceedings of a workshop on the socio-economic dimensions of livestock production in the Communal lands of Zimbabwe Centre for Applied Social Sciences, University of Zimbabwe, Harare (1981).

13. Rao, V.M. Livestock economy of Arunachal Pradesh. In proceeding of $8^{\text {th }}$ annual conference of the Agricultural Economic Association on livestock in different farming systems held at Tamil Nadu Veterinary and Animal University, Chennai, India, November (2000).

14. Veena, D.R. Rural Energy: Consumption, Problems and Prospects, Ashish Publishing House, New Delhi (1988).
15. Sharma, P. Resource utilization pattern with special reference to fuel and fodder in a village Gagrote, district Jammu. M.Sc dissertation. Department of Environmental science, University of Jammu, J\&K (2013).

16. Kumar, D. Studies on some environmental issues of Dandesar village of district Rajouri with special reference to resource utilization. M.Sc. dissertation. Department of Environmental Sciences, University of Jammu, J\&K (2002).

17. Sati, V.P., and Sang, C. Estimation of forest biomass flow in the montane mainland of the Uttarakhand Himalaya. International Journal of Forest, Soil and Erosion, 2: 1-7 (2011).

18. Rawat, Y.S., and Sharma, C.M. Sustainable Development and Management of Forest Resources: A Case study of site specific Microplan Preparation and joint forest management (JFM) Implementation in District Rudraprayag. Central Indian Himalaya. Environment and We; An International Journal of Science and Technology, 5: 1-12 (2010). 